\title{
Foreign Trade Aspects of Economy Security in the Context of Russia's WTO Membership
}

\author{
Podmolodina I.M.* \\ Voronezh State University of Engineering Technologies \\ Voronezh, Russia \\ e-mail:podmin@mail.ru
}

\author{
Voronin V.P. \\ Voronezh State University of Engineering Technologies \\ Voronezh, Russia \\ e-mail: voronin070441@mail.ru
}

\author{
Kolomytseva O.Yu. \\ Voronezh State University of Engineering Technologies \\ Voronezh, Russia \\ e-mail: olgakolom@yandex.ru \\ Kolesnikova E.Yu. \\ Voronezh State University of Engineering Technologies \\ Voronezh, Russia \\ e-mail: elenakoles@yandex.ru
}

\begin{abstract}
The article is devoted to the identification of problems of Russia as a WTO member, related to its foreign trade activities, the analysis of the advantages and disadvantages of this membership and their impact on the foreign trade aspects of ensuring economic and economic security of the country and companies. A reflexive feedback mechanism under the influence of the self-reinforcing interaction of biased opinion and a trend created by thinking and reality is considered. The possibility of its action on commodity markets is substantiated. The hierarchical distribution of reflexivity from the level of individual companies to the country level, the level of supranational governments, and the inclusion of political motives in the formation of biased opinions are investigated. This manifests itself in ignoring the commercial interests of individual economic agents, restricting the freedom of foreign trade in contradiction to the main provisions of the WTO and introducing economic sanctions against individual companies, countries and individuals on this basis, the introduction of embargo on exports of certain types of goods and equipment. It is proved on the basis of the institutional analysis of the hydrocarbon market that the WTO system in modern conditions is unable to provide each country with economic security of foreign trade activities, availability of international credits for domestic investments and financing of foreign trade operations. It was shown that the only effective response of Russia is the introduction of counter sanctions, first of all, on perishable products, which allowed developing its own production more intensively, pursuing a policy of import substitution based on the introduction of new technologies and development of domestic innovation.
\end{abstract}

Keywords - foreign trade aspects, WTO, economic security, reflexivity, sanctions, counter-sanctions, freedom of trade.

\section{INTRODUCTION}

The USSR tried to join the WTO, which it was denied due to the domination of state enterprises in the country's economy and the lack of market relations. Russia had long, 18-year-old negotiations on its accession to the WTO (from 1993 to 2011), of which it became a member only in 2012. It was expected that the Russian foreign economic activity would become more predictable and stable due to the emerging opportunities to take advantage of international trade. However, so far this accession has caused divergent opinions. Conflicting consequences of WTO accession for the Russian economy, as well as the simultaneous application of economic sanctions against it by the U.S. and the EU on political rather than commercial grounds, in accordance with WTO rules, and then - in response to Russia's introduction of counter-sanctions on agricultural products, made it extremely urgent to analyze the foreign trade aspects of our country's economic security.

For the Russian economy, foreign trade is an important form of international economic relations. It serves as a source of capital accumulation, promotes international specialization and production growth in the sectors of the economy. Foreign trade activity depends on a multitude of factors that form threats to the country's economic security. These include:

- reduction of foreign trade turnover;

- increasing influence of foreign policy conditions;

- reduction of prices for raw materials;

- monopolization of foreign trade activities;

- limited opportunities for risk insurance

- Interpenetrating role of national and foreign policy of the country, increasing dependence on world finance;

- growing competition between Russia and other countries in the trade sphere;

- Damage to Russian exports through the use of unjustified discriminatory measures;

- excessive dependence of the economy on foreign shortterm speculative capital and others.

Threats to economic security in foreign trade associated with Russia's accession to the WTO are growing. When Russia joined the WTO, it adopted a favorable trade regime and equalized the rights of foreign companies from different countries in the Russian domestic market.

The WTO member countries with which Russia negotiated its terms of accession insisted and achieved reduction of the import duty to $11 \%$, while the current tariff is $20 \%$. For 
agricultural products the average rate has decreased to $18 \%$, for industrial goods - to $7.6 \%$, and further to $5 \%$, which contributed to the explosive inflow of imports [5] and the displacement from the market of domestic products with a less attractive appearance, imperfect retail.

Now the main countermeasures to threats to economic security in Russia as a whole include the use of protectionism and free trade policy. Developing economies should apply protective measures, due to the need to support economic sectors that emerge and are formed under the influence of scientific and technological progress, as well as to protect them from competitive effective foreign enterprises with extensive experience in the world market [8-11].

There are arguments of opponents of defense policy, among which we can specify the following:

- Illogicality of the defense policy aimed at achieving positive trade balance and restraining import operations. This leads to a reduction in the volume of export operations as a result of similar reactions from international partners, which also leads to an imbalance in trade rather than to a positive result;

- Barrier-protected areas of the national economy lose incentive to innovate as competition from the global market diminishes;

- Multiplier effect of protectionism: The technological interrelationship between industries leads to the fact that, if protection is introduced for some industries in the technological chain, it will also be required for technologically related industries;

- Protectionism can damage the economic interests of consumers, who are forced to pay for imported, dutiable and domestically produced goods;

- The advantages of international specialization are not well exploited, as restrictions are imposed on imports of cheap goods.

In addition to protectionism, free trade policies are developed in equal relative proportions. Free trade is a liberal policy of state non-interference in the process of international trade. The advantages of free trade are as follows:

- Competition processes are intensifying, both among domestic producers and on the world market in general, stimulate commercial activity towards optimization of taxation processes [12];

- International trade is conducted in accordance with the law of comparative competitive advantages;

- Opportunities are created for the use of international specialization, which is the basis of growth for proproducers and consumers, and this contributes to the expansion of the market, creates the basis for mass production and its positive effect [5]

The proponents of free trade justifiably believe that the arguments in favor of protectionism are quite controversial in their essence, because the goals set by proponents of protectionism may well be achieved at a lower cost if real competition develops.

Russia's accession to the WTO has given rise to many contentious and debatable issues in various areas of economic and social activity, both at the state and at the level of individual industries and enterprises. The analysis of the results of theoretical research and current practice reflects a sharp discussion in the field of law enforcement and economic consequences of Russia's WTO membership in the light of the definition of the main directions and search for mechanisms to implement industrial policy in Russia [1] in the context of increasing inter-country competition for raw materials and sales markets and the balance of foreign trade operations. At the same time, the development of globalization processes leads to a decrease in the role of individual countries in domestic markets, to an increase in the intertwining of trade, commercial and currency risks, to an increase in uncertainty and reflexivity in foreign trade activities.

At present, reflexivity is a new threat to economic security.

We understand reflexivity as the influence of the selfincreasing interaction of a biased opinion and the trend created by thinking and reality in the feedback mechanism, which has a self-corrective character. The creator of the world's largest investment fund Quantum, J. Soros, revealing the connection between theoretical notions and people's real behavior, showed how blind and groundless belief in the theory of selfregulation and market self-organization led world capitalism to the crisis which, as a chain reaction, covered one country after another [2], causing contradictions in the foreign trade sphere. He called this phenomenon reflexivity.

Hence, it is difficult to develop a universally recognized opinion on the impact of Russia's accession to the WTO on the economy as a whole and the development of foreign trade activities. On the one hand, the long-awaited and, to a great extent, pliable Russia's accession to this organization helped to intensify the penetration of transnational companies into the Russian market, to integrate the country into the world economic relations, and to bring Russian companies into international markets. On the other hand, Russia's accession to the WTO, creating new opportunities for enterprises in the foreign trade sphere, simultaneously created new threats to national and economic security [3].

\section{RESULTS}

New opportunities for producers and exporters are presented in the form of the most favorable conditions for their entry into international markets with domestic goods, protection of the interests of Russian companies in the foreign market, giving Russia a voice in the development of new multilateral agreements and other factors of self-enforcing and self-correcting reflection. Ignoring it contributes to the emergence of new threats in the national economy. There is a decline in production in uncompetitive industries on the world market, and unemployment is on the rise as a result of the decline in production in uncompetitive industries.

The advantages and disadvantages of Russia's WTO membership are systematized in Table 1. 
The synthesis of analysts' assessments and Russian researchers' conclusions allows formulating the following reflexive consequences from Russia's accession to the WTO in the form of threats to economic security:

- a significant reduction in the production of light and food industry enterprises in the inexpensive sector, a decrease in the production of inexpensive drugs and electronic industry products, the shutdown of competitive aircraft manufacturing, which corresponds to the diverse climatic and geographical conditions of our country;

TABLE I. ADVANTAGES AND DISADVANTAGES OF RUSSIA'S ACCESSION TO THE WTO

\begin{tabular}{|l|l|}
\hline \multicolumn{1}{|c|}{ Advantages of accession } & Deficiencies of WTO membership \\
\hline WTO system contributes to peace & The WTO dictates its policy \\
\hline Constructive dispute settlement & $\begin{array}{l}\text { WTO stands for free trade at all } \\
\text { costs }\end{array}$ \\
\hline $\begin{array}{l}\text { Free trade helps reduce the cost of } \\
\text { living }\end{array}$ & $\begin{array}{l}\text { Commercial interests have priorities } \\
\text { over development; health and } \\
\text { safety; environmental safety }\end{array}$ \\
\hline $\begin{array}{l}\text { Greater choice of products is } \\
\text { provided, which promotes } \\
\text { competition for quality }\end{array}$ & $\begin{array}{l}\text { WTO reduces jobs, exacerbating } \\
\text { the poverty problem }\end{array}$ \\
\hline $\begin{array}{l}\text { Free trade contributes to increased } \\
\text { income }\end{array}$ & $\begin{array}{l}\text { Small countries find themselves } \\
\text { disempowered within the } \\
\text { framework of WTO }\end{array}$ \\
\hline $\begin{array}{l}\text { Free trade contributes to economic } \\
\text { growth }\end{array}$ & WTO is a powerful lobbying tool \\
\hline $\begin{array}{l}\text { Basic principles make life more } \\
\text { efficient and rational }\end{array}$ & $\begin{array}{l}\text { Weaker countries are forced to join } \\
\text { WTO }\end{array}$ \\
\hline $\begin{array}{l}\text { The governments of the } \\
\text { participating countries are getting } \\
\text { rid of their lobbying activities. }\end{array}$ & Non-democratic organization \\
\hline $\begin{array}{l}\text { Established and adopted rules make } \\
\text { life easier }\end{array}$ & $\begin{array}{l}\text { WTO rules are not in all cases } \\
\text { acceptable to Russia }\end{array}$ \\
\hline
\end{tabular}

- the disappearance of the agro-industrial complex not only because of worn-out machinery and harsh climatic conditions, but also because of the forced destruction of successful agro-industrial clusters, purely market collective farms based on share premiums from farmers, collective farms and consumer cooperatives;

- increased unemployment as a result of reduced production and mass bankruptcy of enterprises, especially in small and medium-sized businesses;

- degradation of mono-cities and rural settlements due to their dependence on the only city-forming entity - a factory or production;

- food insecurity resulting from WTO agreements where imported goods are considered to be similar and GMO content designations are considered discriminatory measures applied by the country;

- the risk of absorption by national financial institutions of the banking and insurance sectors as the least prepared to compete with Western organizations;

- loss of energy sovereignty of Russia due to reduction of export duties on energy resources; state sovereignty in the form of prohibition of industrial policy oriented to national interests; political sovereignty limited by WTO norms;

- weakening of the legal framework in the field of environmental security, which does not fit into international treaties on environmental protection, i.e. the effect of some international norms is actually limited to the effect of others;

- reduction of engineering services as an object of international trade [7].

There is no doubt that Russia has also obtained certain advantages from WTO accession, which it did not have before. Their comparative characteristic is presented in Table 2.

The variety of factors and prevailing conditions made it more difficult to assess the impact of Russia's WTO accession on the development of foreign trade from the point of view of economic security.

TABLE II. COMPARATIVE CHARACTERISTICS OF CHANGES IN THE FOREIGN TRADE REGIME BEFORE AND AFTER RUSSIA'S ACCESSION TO THE WTO

\begin{tabular}{|l|l|}
\hline \multicolumn{1}{|c|}{ Before joining } & \multicolumn{1}{c|}{ After joining } \\
\hline $\begin{array}{l}\text { Discrimination of access of Russian } \\
\text { goods to international market }\end{array}$ & $\begin{array}{l}\text { Free access of Russian goods to } \\
\text { international market }\end{array}$ \\
\hline $\begin{array}{l}\text { Impossibility of Russia's } \\
\text { participation in development of } \\
\text { international trade rules }\end{array}$ & $\begin{array}{l}\text { Possibility of Russia's participation } \\
\text { in development of international } \\
\text { trade rules }\end{array}$ \\
\hline $\begin{array}{l}\text { Absence of large-scale attraction of } \\
\text { foreign investments into the } \\
\text { economy }\end{array}$ & Increasing investment attractiveness \\
\hline $\begin{array}{l}\text { Uncertainty of customs and tariff } \\
\text { policy }\end{array}$ & $\begin{array}{l}\text { Stability and transparency of } \\
\text { customs legislation }\end{array}$ \\
\hline $\begin{array}{l}\text { Restriction of the WTO court } \\
\text { decision to the scope of the } \\
\text { applicant enterprise only }\end{array}$ & $\begin{array}{l}\text { Access to the quasi-judicial system } \\
\text { of resolving economic disputes } \\
\text { within the WTO on the basis of the } \\
\text { sectoral approach }\end{array}$ \\
\hline
\end{tabular}

The analysis of the state of world markets, the most important foreign trade commercial relations in different branches of the economy showed the increase of competitive tension not only between the largest companies, international and transnational corporations, but also between their countries of origin. As a result, there are two aspects of economic security threats:

- A departure from the WTO-declared basic principle of ensuring foreign trade freedom;

- Intervention of the world's leading states in international trade under biased political pretexts in order to support their national producers and promote their products on the world markets, as well as exerting pressure on competing countries to limit their independence in foreign trade operations.

Both the first and the second are contrary to the main provisions of the WTO, and their intertwining reflects an emerging reflexivity that often does not serve the economic interests of national companies and the country as a whole.

Thus, we propose a hypothesis of the spread of reflexivity on commodity markets under the influence of the self- 
reinforcing interaction of biased opinion and the trend created by thinking and reality.

This is especially evident in the hydrocarbon market, the most important raw material for industry, power generation and utilities, which shows dynamic growth. According to forecasts, expected natural gas imports to the European Union by 2030 may increase to 512 billion $\mathrm{m}^{3}$ per year, which is 1.6 times more than in 2007. ( 312 billion $\mathrm{m}^{3}$ per year). This entails a significant increase in the demand for Russian gas supplies to the global and European markets. It would seem that under these conditions all countries - gas suppliers and buyers have the same commercial interest. However, due to their reflexivity, some countries are guided by a biased opinion which should have been suppressed by the WTO rules through the mechanism of an arbitration court.

Based on the long-term forecast for the growth of gas demand in the EU countries and based on its commercial interests, Russia proposed Poland to build an additional branch of the gas pipeline along a shorter route through Belarus to Germany. Poland withdrew the offer on the pretext that it did not have free land, although the economic and strategic benefits were obvious. Russia approached Lithuania with a similar proposal and was again refused with the same motivation. A third compromise commercial proposal was made to draw an additional line of the gas pipeline along the border line between these countries. But this option was also rejected despite the obvious commercial benefits. In this case, the reflexivity in the actions of the leaders of the mentioned states was based on the biased opinion about the possibility to get some additional concessions through pressure on Russia, which were not justified. As a result, these countries have lost a stable income for pumping gas and could not become its distributor (hub) for other Western European countries.

Russia has found an alternative, shorter but also more expensive way. Together with Germany, an alternative international project "Nord Stream" was developed and implemented as the offshore part of the North European gas pipeline. The gas pipeline between Russia and Germany runs through the Baltic Sea as part of one of the branches of the Yamal-Europe gas pipeline system. This branch also includes the OPAL and NEL pipelines in Germany. The Nord Stream project involves Russia, Germany, the Netherlands and France. The USA and the Baltic countries, which are the transit countries for Russian gas, have opposed its implementation. At the same time, Estonia first agreed to participate in this project, but then withdrew it. Once again, the reflexivity and bias of opinion affected the preference of the Finland-Estonia-LatviaLithuania gas pipeline construction. Its implementation was stubborn in the absence of its own financial resources, and the EU did not fund the project.

The EU has allocated funds to Lithuania to finance the construction of a hub to receive liquefied gas from the USA. There was nothing to fill it with and Lithuania started buying Russian gas from Poland, but it was 15 percent more expensive. Consequently, Lithuanian consumers received more expensive gas, and the transit revenues turned out to be phantom. The delivery of gas through two lines of the pipeline in commercial mode began in October 2012.
The principle of reflexivity is also characteristic for the activities of supranational bodies - the European Commission, the European Court, etc. The European Union seeks to create a single gas market, which can contribute to the energy security of each of the EU countries. In case of difficulties in one of the countries, it will be able to get gas from the other country. In this regard, since 2009, European Commission (EC) directives have required EU pipeline owners to provide equal access to all potential gas suppliers at affordable prices by reserving 50 per cent of each pipeline capacity for this purpose. In this connection, the EC has granted Gazprom 90 percent of the capacity of OPAL, the onshore extension of Nord Stream through Germany, in a decision of 2013. However, in September 2019, the EU court overturned this decision in a lawsuit filed by Poland.

There is a self-reinforcing interaction of biased opinion and trends created by thinking and reality. The EU court considered that Gazprom's full access to the pipeline could reduce the transit of Russian gas through Poland, which would violate the EU energy solidarity principle. But by doing so, the EU court established the dependence of the foreign trade deal between Russian and German businesses on a third country. This not only violates the relevant WTO provisions, but also infringes on Russia's national sovereignty. Thus, Russia's WTO membership proved to be unable to protect Russia from the impact of reflexivity based on the biased opinion formed by the EU governing body. After all, the national sovereignty of the country, as the basis of economic security, presupposes the ability of the country to create around itself a space for development and stability to ensure favorable conditions for foreign trade operations based on long-term contracts.

At the current stage of development of world economic relations, reflexivity is manifested as the influence of selfreinforcing interaction of biased opinion on a biased political basis irrespective of economic interests of other countries and is a form of unfair competition. This includes the imposition of economic sanctions against legal entities - companies, individual individuals and even against individual countries in the form of a ban on foreign trade operations with them, supply of modern equipment purchased in the foreign market, creative and financial operations, provision of long-term loans, as it is common in the world practice of foreign trade operations. The distinctive feature of reflexivity is the compulsion of third countries to carry out it under the influence of financial threats, despite the absence of a legal basis and the economic damage caused to them, as opposed to and ignoring the WTO arbitration court designed to protect their rights to free trade.

Economic sanctions imposed on Russia in contravention of the WTO requirements de facto negate the effect of its accession to this organization. Russia, in turn, was forced to introduce counter sanctions: a ban on the port of perishable food products from these countries. At the same time, strange as it may seem, countries threaten Russia with a WTO arbitration court for violation of rules that they themselves ignore. Russia has justified its policy of supporting domestic producers by taking a course on import substitution. As a result, new jobs, new markets, technologies and production based on innovation are being improved. Thus, the balance of positive and negative 
consequences of Russia's participation in the WTO is assessed as contradictory. Besides, on the one hand, another wave of the global financial crisis imprints on it, and on the other hand, the shortcomings of the very mechanism of management in Russia. This can be clearly seen in the dynamics of the cheese market, which has been supplemented with new varieties of domestic cheese, as well as cheese produced in Russia by joint ventures, which are not subject to counteraction.

Another foreign trade aspect of economic security is the corporate culture, which has been intensively developing lately as a tool to adapt transnational corporations (TNCs) to Russian economic conditions.

"The specifics of the national economy and the specifics of the business environment to a large extent determine the possibilities of TNK's activities and predetermine the search for a set of tools to facilitate, on the one hand, the adaptation of corporations to the Russian business environment and, on the other hand, the acquisition by the host country of additional competitive advantages and the introduction to modern management methods" [6].

From scientific positions it promotes such interaction of the reasonable opinion and the tendency created by thinking and reality which results in increase of culture of interaction in the course of formation of foreign trade contracts that promotes the decision of problems of maintenance of economic safety of our country.

The existing conditions and tendencies of dominance of certain countries in the world trade created a situation when competitiveness and achievement of strategic goals are determined by the results of activities in the industrial sector [4]. Besides, due to the introduction of anti-Russian economic sanctions, reduction of the state budget revenues, reduction of the world prices for energy resources, the management of industrial development began to be based on the principles of endogenous growth.

The current conditions for the development of the foreign trade market imply the search for unaccounted elements of price formation, which, although subjectively, will be able to most accurately justify the cost of goods. Most foreign trade companies have individual features of their products with high competitiveness [6].

According to the world practice, the lower the firm's influence on the market, the less it can prevent price adjustments and, consequently, a simpler pricing system.

It should be noted that a fall or rise in prices for imported products, the imposition of such an instrument as an embargo on trade with individual countries or a group of countries that are considered to be the most important markets or suppliers of products, are also dangerous factors for the economy. The inadmissibility of high dependency on the supply of certain products from a single country or group of countries allows many countries to exploit that dependency and allows creditors to impose conditions on foreign economic relations.

To prevent threats to economic security in foreign trade, the concept and strategy of foreign economic security is needed. Unfortunately, in Russia there are no such documents, except for the basic document "National Security Strategy of the Russian Federation until 2020", which is supposed to be:

- Further improvement of the production and export structure, anti-monopoly regulation and support of competition policy;

- Significant strengthening of financial markets and liquidity of the banking system;

- Development of a national innovation system for the implementation of highly effective projects and priority programmes for the development of high-tech industries;

- Formation of the system of scientific and technical forecasting and implementation of scientific and technological priorities;

- Strengthening integration of science, education and production;

- Development of information and telecommunication technologies, computer technology, radio electronics, telecommunication equipment and software;

- Development of new resources; modernization of priority branches of the national economy [15].

However, in order to implement the main directions of the foreign economic policy it is necessary to have documents reflecting [16]: priorities of the customs-tariff policy; programs for promotion of export activity; plans of trade and economic cooperation with foreign countries.

None of these documents has been developed and adopted yet. Normative acts mainly take into account price factors of support of a national commodity producer.

For effective management of the country's economic security in foreign trade there is a need for a mechanism to counteract threats to economic security, based on a combination of organizational structures, methods, techniques and methods, as well as legal norms used to achieve the interests of the state or its subjects of foreign economic activity, resistant to external and internal threats and guaranteeing the growth of the living standards and quality of life of its citizens [4]. To counteract negative factors and threats in foreign economic activity, it is necessary:

- To achieve an excess of the growth rates of the export of services over the export of goods;

- To create a system of legal regulation of export-import transactions;

- To regulate Russia's relations with foreign countries in the sphere of foreign economic activity taking into account their contribution to development and ensuring economic security;

- To provide a detailed elaboration of the issues of customs, licensing and export-import quotas; 
- To exercise control over the establishment of responsibility for the violation of legislation on foreign economic activity.

In addition, new measures are needed to support the development and ensuring the economic security of the country.

Currently, even existing measures to support exporters are not used effectively due to the complexity of procedures, excessive requirements for exporting companies, and lack of state financial security.

\section{CONCLUSION}

The conducted researches of foreign trade aspects of economic security allowed revealing threats, which include monopolization of foreign trade activity, reduction of foreign trade turnover, strengthening of influence of foreign policy conditions, as well as reduction of prices for raw materials, reduction of production in uncompetitive branches of Russian industry. The advantages and disadvantages of Russia's WTO membership were identified, and a comparative characteristic of the benefits obtained by Russia from WTO accession was formed. Taken together, this makes it possible to provide the most general assessment of foreign trade aspects of ensuring economic security. In addition, it is proposed to use the characteristic of a reflexive feedback mechanism that arises under the influence of a self-reinforcing interaction of biased opinion, reinforced by the intertwining of trade, commercial and monetary risks and increasing uncertainty, and a trend created by thinking and reality. It has been proved that the reflexive mechanism is characteristic not only for financial markets, but also for commodity markets, it is formed as a vertically integrated structure, and arises not only in the activities of individual companies, but also at the level of the country and even at the level of supranational bodies. The reflexive mechanism has revealed a tendency to outgrow biased opinions into politically biased ones aimed at restricting the freedom of foreign trade and the inability of the WTO mechanism to counteract this threat to economic security.

\section{References}

[1] I.M. Podmolodina, V.P. Voronin, E.M. Konovalova, "Main directions and mechanisms of industrial polisy of Russia", Asian Soc. Sci., vol. 11, no. 20 , pp. $170-177,2015$

[2] G. Soros, The crisis of global capitalism. Open Society Endangered. Moscow: INFRA-M, 1999, $262 \mathrm{p}$.
[3] Reasons, conditions and consequences of Russia's accession to the WTO. Retrieved from: https://www.eurasialegal.info.

[4] E.V. Tokar, "Development of Foreign Trade as a Direction for Ensuring Economic Security of the Russian Federation", West. Belg. unta cooperat., econ. and law, vol. 5, no. 72, pp. 37-49, 2018.

[5] A.N. Spartak, "Perestroika in Russian Export", Russ. Foreign Econ. Bull., no. 4, pp. 3-13, 2017.

[6] I.M. Podmolodina, V.P. Voronin, "Business Analysis as an Important Component of Ensuring Enterprise's Economic Security, Business Analysis as an Important Component of Ensuring Enterprise's Economic Security", Europ. Res. Studies J. Int. Strategic Manag. Associat., vol. XX, iss. 3B, pp. 239-249, 2017

[7] N.G. Sokolova, A.N. Lobanova, "Engineering Services as an Object of International Trade", Bull, of Udmurtia Univer., Econ. and Law Ser., vol. 28, no. 3, pp. 366-372, 2018.

[8] Y.A. Salikov, V.S. Mikhailiuk, "Methodological approach to the terminological analysis of the key concepts of economic security", Proc. of the Voronezh State Univer. of Engineer. Technol., vol. 81, no. 2, pp. 387-392, 2019. Retrieved from: https://doi.org/10.20914/2310-12022019-2-387-392

[9] J.V. Narolina, Sabetova T.V., Shabutskaya N.V., N.V. Gryshchenko, "The influence of innovative development on economic security of the region", Proc. of the Voronezh State Univer. of Engineer. Technol., vol. 81, no. 1, pp. 457-463, 2019. Retrieved from: https://doi.org/10.20914/2310-1202-2019-1-457-463

[10] A.I. Khorev, E.V. Gorkovenko, I.V. Platonova, "Economic security of the Central Black Earth region: assessment of the state and threats", Proc. of the Voronezh State Univer. of Engineer. Technol., vol. 80, no. 3, pp. 368-376, 2018. Retrieved from: https://doi.org/10.20914/2310-1202-2018-3-368-376

[11] Y.M. Sokolinskaya, E.A. Kolesnichenko, "Criminalization as a main threat to economic security", Proc. of the Voronezh State Univer. of Engineer. Technol., vol. 81, no. 1, pp. 480-484, 2019. Retrieved from: https://doi.org/10.20914/2310-1202-2019-1-480-484

[12] A.I. Khorev, G.V. Belyaeva, A.N. Polozova, R.V. Nuzhdin, "The optimization procedure in the tax system, the processing organizations", Proc. of the Voronezh State Univer. of Engineer. Technol., vol. 81, no. 1, pp. 357-365, 2019. Retrieved from: https://doi.org/10.20914/ 2310-1202-2019-1-357-365

[13] V.V. Kurchenkov, O.V. Fetisova, A.A. Orlova, E.A. Gladkaya, "The importance of the regions economic activity evaluation in Russia, 20122016”, Revista Galega de Econ., vol. 26, no. 3, pp. 33-444, 2017.

[14] E.S. Mityakov, Development of methodology and tools for monitoring the economic security of Russian regions. Retrieved from https://www.vyatsu.ru.

[15] O. Kolomytseva, E. Kolesnikova, I. Gunina, V. Agafonova, "Managemrnt of the innovative ecosystem development environment", p. 08067, 2019 [E3S WEB OF Conf.]. DOI: 10.1051/e3sconf/20199108067.

[16] National Security Strategy of the Russian Federation until 2020. Retrieved from: http://www.garant.ru.

[17] Concepts of Economic Security of the Russian Federation until 2020. Retrieved from: http://www.garant.ru. 